\title{
GEORGE BARTON AND THE ART OF FRIENDSHIP
}

\section{Peter McKenzie*}

This address was given at the special sitting of the High Court in Wellington for Dr George Barton QC by Peter McKenzie on 6 July 2011.

May it please your Honours,

I feel the weight of the responsibility that rests on me in speaking at this special sitting. I stand here on behalf of a very large number of lawyers who were friends of Dr George Barton. I am also speaking for the members of the New Zealand Bar Association who have always had a special regard for Dr Barton as undoubtedly their most senior and respected member. I am also very conscious that George Barton, with characteristic modesty, was someone who disliked talking about himself. Although he would have enjoyed an occasion like this as an opportunity to greet so many of his friends, he would not approve of much of what I am going to say.

Others have spoken of his professional life and achievements. I would like to touch on him as a legal colleague and a friend. I say "touch on" advisedly because there is so much one could say.

Dr Barton had an enormous capacity for friendship and had that special gift of making those of us who knew him feel that we were each his special friend. I, like them, miss him greatly.

His network of friends was drawn widely from his time both as an academic and as a practising lawyer. He had, as those who confronted him at the bar knew, a prodigious memory and this extended to the names and faces of students he had taught during his more than 20 years at the Victoria University of Wellington Law School. Years later he could name and recount some detail of students he had taught. John Upton QC and Richard Peterson, who recently organised a reunion with him of students from their year, I think 1963, can testify to this. There would be few lawyers in Wellington, in their late 50s and beyond, who were not taught by him (as I was) and felt a special bond and affection for him. That was particularly true of the women in the profession who from earlier years were much fewer in number.

* Peter McKenzie QC was from 1966 to 1976 a colleague of Dr Barton's on the Law Faculty of Victoria University of Wellington. During this period from 1969 to 1975 he shared barristers' chambers in Lambton Quay, Wellington with Dr Barton. 
I do not believe there was a single academic from outside New Zealand who was on the Victoria University of Wellington Law Faculty staff during George's time there that he did not continue a correspondence with and make a point of visiting while he was at one of the many international law conferences that he attended.

He also maintained links with his overseas students and would frequently bring me up to date on their progress back in their own countries where many reached high judicial office. From those ongoing friendships George developed a practice in a number of jurisdictions including Sabah, Sarawak and Samoa. To this could be added the different set of friendships built up over his 45 years on the board of management of the Bible Society, and the international network built up in his recent years as World President. The letters that have been coming in from around the Bible Society world testify to this.

Emerson once said "Keep your friendships in repair" and George modelled that advice.

Throughout these years George had the loyal support of Ailsa and this extended to the considerable entertaining that was involved including, in earlier years, students from his classes. Over the years there have been many overseas visitors too.

Dr Barton's involvement with younger practitioners went well beyond maintaining friendships. I have had so many practitioners tell me how they were mentored and encouraged by him, how he patiently heard their questions and gave advice and were given briefs to start them out at the bar. That was very much my own experience. It was George Barton who wrote to me in England and encouraged me to apply for a lectureship at the Victoria University of Wellington Law Faculty, welcomed and mentored me on arrival and asked me whether I had thought of setting up a part-time practice as a barrister. Later he invited me to join him in chambers at 106 Lambton Quay, at first with Don Mathieson and later, when Don moved on, with Jim Seeman. They were wonderful colleagues and I owe much to those years with them. George fed me a regular diet of opinions and briefs to get me started and my first two appearances in the Court of Appeal were as his junior. I had the special privilege of sharing chambers with him, but in other ways my experience was that of many others.

It is not possible to do justice to George without mentioning his humour. He enjoyed playing practical jokes on some of his erring colleagues. He and his friend the late Judge Ramon Pethig were masters of the art of impersonating one of the judiciary or a senior police officer or President of the Law Society and ringing a colleague about some alleged misdemeanour on which the wrath of the law was about to break. My experience was limited to his impersonating an aggrieved client.

I cannot resist two incidents that reveal not only his humour but that Scottish tenacity that were features of him.

He inhabited a variety of chambers over the years starting with the late Don Inglis on the corner of Johnston and Featherston Streets when I was a student and migrating later to an old wooden 
building in Bolton Street. It became clear that the landlord had other ideas for this building and one by one the tenants, including Don Inglis, moved out leaving only George. He had a right of renewal and, being George, he chose to exercise this in what was now an almost deserted building. The landlord was not pleased and, call it coincidence if you will, there were three occasions late at night when George was summoned hurriedly by the Presbyterian Minister who lived over the road to come and rescue his chambers which were on fire. After the first attempt George moved his library and papers out but he stayed on. At the third attempt even George was forced to vacate but I think the honours went to him.

I am indebted to Gary Turkington for reminding me of this next story. At a later stage, George took a flat in the Hobson Court apartment block as his chambers but had not been there long when tenants in the building complained that he did not have resource consent and must move out. He was clearly quite nonplussed by this, given his low profile and respectable practice. He told me of it saying: "They seem to think I'll have unconvicted murderers and rapists visiting my chambers but, come to think of it Peter, I guess you could call me an unconvicted murderer or rapist. I haven't been convicted of either".

For those of us in Wellington it was coffee with George that will stay in our memories. My memory goes back to the Buttery in Woodward Street but there would certainly have been some earlier place to which lawyers would resort to find and exchange stories with George. In recent years Roy Parsons' became the place of resort, especially for the criminal bar. Others of us were enticed out for afternoon coffee with George promising that he had some special news to share. He certainly delighted in passing on the latest legal news - dare I call it gossip? He was a remarkable clearinghouse for news or perhaps tips on judicial appointments, and anecdotes from the latest case or stories of some figure from Wellington's legal past to illustrate some current infamy or perhaps victory. I tried at times to trump him with a story he had not heard. I never succeeded. He always had it first.

Indeed he was something of an institution. So many have said to me: "We just imagined George would always be around. He seemed indestructible", and indeed I find it hard not to rub my eyes as I walk down the far end of Lambton Quay and think I see him coming towards me and asking "What's the latest news?"

These times with George were also invaluable times for asking his advice on some difficult issue of professional ethics or on some archaic principle on which other legal sources could throw little light. He almost always had an answer and, if he did not have it at the time, you would receive a note on the fax a few days later crafted in his neat precise handwriting (written by the left hand of course) suggesting you might like to look at a particular authority or unknown text or article. On professional ethics George became something of an oracle. He served on the New Zealand Law Society Disciplinary Committee for many years but was also consulted widely both professionally and informally. 
I am sure he had the confidence of the profession on ethical matters because he modelled the ethics that he referred to. A whole generation of barristers has looked to him as providing a living example of the integrity, independence, courage, humanity and dignity that should characterise a court lawyer. These were values that seemed as much part of him as the strong Christian convictions that supported them - convictions that he never wore on his sleeve but were simply part of the way he lived.

As I have reflected on him I believe that he was in the best sense of that word a Puritan, but certainly one with a chuckle and enjoyment of life. It has been said of the Puritans that for them God's greatest work of art was a well crafted life, the life well lived. For that we are all in his debt.

Chief Justice, your Honours, may it please the Court. 